\title{
PUBLIC HEALTH SAFETY IN RELATION TO MICROBIOLOGICAL QUALITY OF FRESHLY DRAWN COW'S MILK IN BANGLADESH
}

\author{
R. Khaton ${ }^{1 *}$, M. A. Hasnat ${ }^{2}$, S. Rahman ${ }^{1}$, M. M. Rahman ${ }^{2}$ \\ ${ }^{1}$ Department of Animal Husbandry and Veterinary Science, Faculty of Agriculture \\ University of Rajshahi, Rajshahi-6205, Bangladesh \\ ${ }^{2}$ Department of Microbiology and Hygiene, Bangladesh Agricultural University \\ Mymensingh-2202, Bangladesh
}

\begin{abstract}
The aim of the present study was to determine the microbial quality of freshly drawn cow's milk belonging to the arsenic affected and non-affected areas. In the present work 25 milk sample were collected from five different arsenic affected and non-affected areas. The analysis comprised enumeration of total viable count (TVC), total coliform count (TCC) and total staphylococcal count (TSC) for the determination of sanitary quality. The highest total viable count, total coliform count and total staphylococcus count were $\log 5.894 \pm 0.221, \log 2.832 \pm 0.129$ and $\log 2.898 \pm 0.162$ respectively. Staphylococcus spp, Escherichia coli, Pseudomonas spp and Bacillus spp were isolated from the milk samples. Among them Escherichia coli were isolated from the maximum milk samples. It is found that the level of microbial quality in terms of TVC, TCC and TSC were high in arsenic affected areas than arsenic non-affected area. It also found that TVC and TCC were positively correlated with each other. This survey indicates that most of the raw milk samples were not satisfactory in course of public health standard as some pathogenic bacteria were detected from these samples and it is necessary to improve the hygienic practices required for the handling and processing of milk.
\end{abstract}

Key words: Microbial quality, milk, total viable count, total coliform count, total staphylococcal count

\section{INTRODUCTION}

Milk and milk products are ideal foods for all age groups in both rural and urban people all around the world (U.S. Public Health Services, 1965). Milk constituents include water (87.20\%), protein (3.50\%), fat (3.70\%), milk sugar or lactose $(4.90 \%)$, ash $(0.70 \%)$ and dry matter (12.80\%) (Byron et al., 1974). The milk and milk products derived from milk of dairy cows can harbor a variety of microorganisms and can be important sources of food-borne pathogens. The presence of food-borne pathogens in milk is due to direct contact with contaminated sources in the dairy farm environment and to excretion from the udder of an infected animal (Oliver et al., 2005). Illness caused by the consumption of contaminated foods has a detrimental impact on the economy and the public health worldwide (Mead et al., 1999). Milk is synthesized in specialized cells of the mammary gland and is virtually sterile when secreted into the alveoli of the udder (Tolle, 1980). Beyond this stage of milk production, microbial contamination can generally occur from three main sources (Bramley and McKinnon, 1990) from the udder, from the exterior of the udder and from the surface of milk handling and storage equipment. Bacterial contamination of freshly drawn cow's milk can also originate from different sources: air, milking equipment, feed, soil, feces and grass. Public health problems associated with the consumption of unpasteurized cow milk and raw milk products has been well documented (Cody et al., 1999; Baird-Parker and Bruce Tomkin, 2000; De Valk et al., 2000; De Buyser et al., 2001; Harrington et al., 2002). It is hypothesized that differences in feeding and housing strategies of cows may influence the microbial quality of milk (Coorevits, 2008). High coliform counts of a food indicate potential public health hazards related to food. Normally Staphylococcus is found in the nasal cavity and skin of man and animal. It is important to note that the presence of Staphylococcus in food represents human health hazard as well as associated with food-borne diseases of man. This organism also causes intramammary infection and was found to be highly resistant to antibiotics (Kyozaire et al., 2005). The quality and safety of milk and milk products were determined by the presence of indicator bacteria and other bacteria in lesser number.

*Corresponding e-mail address: rashidavet@yahoo.com 


\section{R. Khaton and others}

Water is the most important nutrient in animal feeds and if drinking water was contaminated with arsenic then animal takes a large amount of arsenic per day. In Bangladesh arsenic contaminated rice straw and husk were widely used as feed for cattle (Jahiruddin, 2002). Arsenic uptake and accumulation in plant were greatly affected with increasing water and soil arsenic levels (Marin et al., 1992 and Abedin et al., 2002). It is found that the level of microbial quality in milk are high in arsenic affected areas than arsenic non-affected area. Arsenic enters into human through food chain. Moreover, dairy milk and beef are also reported to contain arsenic (Awal, 2003). In Nazirpur thana of Pirujpur district of Bangladesh, few cattle died of arsenic poisoning by drinking arsenic contaminated water and milk of affected dairy cows contained arsenic (Awal, 2001). Supply of safe and sound food to consumer is a major responsibility for veterinarian. According to European Union Standards for Raw Milk Production, the bacterial count should be less than $10^{5} \mathrm{cfu} / \mathrm{ml}$. So, microbiological assessments have an important role to play in the dairy industry to protect the public health and can reduce economic losses by the early detection of inadequate processing, packaging or refrigeration. So its needs immediately detection of micro-organisms from cow that have significant contribution in food chain by milk. Under these circumstances, the present research was undertaken with a view to determine the microbial quality of freshly drown cow's milk inhabiting arsenic affected and non-affected areas and taking arsenic contaminated water.

\section{MATERIALS AND METHODS}

To conduct this research microbial content of arsenic affected areas were selected based on prior study and the arsenic surveillance report published by Department of Public Health Engineering (DPHE). The areas from where samples were collected are:

Area 1: Bangladesh Agricultural University dairy farm of Mymensingh district

Area 2: Sujanagar thana of Pabna district

Area 3: Faridganj thana of Chandpur district

Area 4: Kulaura thana of Moulavibazar district

Area 5: Sadar thana of Bogra district

Area 1 comprises non arsenic affected area and taken as control and remaining 4 were arsenic affected area.

\section{Collection of samples}

The apparently healthy lactating cows were selected as the source of sample. All of these cows received drinking water from tube-well and without providing any arsenical feed supplements. From the selected areas milk samples were collected directly from the udder. Prior to collection the udder was washed with fresh water and the udder surface was dried by using a towel. A quantity of $25 \mathrm{ml}$ milk was drawn from each cow and collected aseptically. For milk collection sterile screw capped tubes were used. From each area 5 milk samples were collected and brought from the experimental site as early as possible. Milk samples were transferred in a large wide mouthed thermo flask containing good quality ice thus maintaining the temperature to about $4^{0} \mathrm{C}$.

\section{Preparation and examination of milk samples for the determination of sanitary quality}

To determine the sanitary quality from each group only five representative milk samples were subjected to microbial quality examination. All steps of preparation of milk samples and determination of their sanitary quality are carried out using sterile sampling equipment and procedure as per recommendation of International Commission for the Microbiological Specification of Foods (1986).

\section{Isolation of microorganisms from milk samples}

Serial dilutions of samples were made up to $10^{7}$ in sterile normal saline.

\section{Enumeration of total viable count (TVC)}

The total viable bacterial count was carried out by the spread plate technique. This enables the number of living organisms or clumps of organisms (i.e. colony forming units) in a form sample to be counted, subject to the appropriate medium and incubation conditions being used. For the determination of total viable counts, $0.1 \mathrm{ml}$ of each ten folds dilution was transferred and spread on PCA agar using a sterile pipette for each dilution. The diluents samples were spread as quickly as possible on the surfaces of the plate with a sterile glass spreader. The plates were kept in an incubator at $37^{\circ} \mathrm{C}$ for 24 to 48 hours and then count colonies. The average number of colonies in a particular dilution was multiplied by the dilution factor to obtain the total viable count. The total 
viable count was calculated according to ISO (1995). The results of the total bacterial count were expressed as the number of organism or colony forming units per gram (CFU/gm) of milk sample.

\section{Enumeration of total coliform count (TCC)}

For the determination of total coliform count the procedures of sampling, dilution and streaking were similar to those followed in total viable bacterial count. For the determination of total coliform count, o.1 ml of each tenfold dilution was transferred and spread on MacConkey agar. The diluted samples were spread as quickly as possible on the surface of the plate with a sterile glass spreader. The plates were kept in an incubator at $37^{\circ} \mathrm{C}$ for 48 hours and then count colonies. The results were expressed as the number of organism or colony forming units per gram (CFU/gm) of milk sample.

\section{Enumeration of Total Staphylococcal Count (TSC)}

For the determination of TSC the procedures of sampling, dilution and streaking were similar to those followed in total viable bacterial count. Only in case of staphylococcal count, Mannitol salt agar was used. The calculation for TSC was similar to that of total viable count.

\section{Morphological characterization by Gram stain}

Respective bacteria colonies were characterized microscopically using Gram's stain as per recommendation of (Merchant and Packer, 1967).

\section{Use of statistical calculation for processing of data}

Data on the total viable count, coliform count and staphylococcal count $/ \mathrm{ml}$ of milk sample were analyzed statistically using one way analysis of variance and correlation with the help of the SPSS software to find out the level of significance and determine any significant correlation between the variable factors.

\section{RESULTS AND DISCUSSION}

In view of the above perspectives, the present study reflects an approach to the recognition of potential public health hazard microbial content in cow's milk in different arsenic affected and arsenic non affected areas.

The total viable bacterial count is the number of bacteria in a sample that can grow and form countable colonies on Nutrient agar after being held at $37^{\circ} \mathrm{c}$ for 24 hours. The data presented in the Table 1 reflects the value of TVC per ml of milk sample collected from different arsenic affected and non-affected areas. According to the Table 1 it is clear that the bacterial count was not uniform and there prevails clear fluctuation. The highest total viable bacterial count $(\log 5.894 \pm 0.221)$ was found in area 4 that may results from poor sanitary condition of dairy yard, increase contamination of body surface by feces and soil, lack of washing of animal and unsanitary milking utensils and the lowest total viable count $(\log 5.546 \pm 0.221)$ was found in area 1, it may results from the relatively better hygienic status due to organized dairy farm production system, better quality of water, and short period of transportation and preparation of sample. This finding strongly supports with the findings of Sandu and Man (2006). The present study results strongly supports with the findings of Lee et al. (1983) and Muehlherr et al. (2003)) who founded that the total bacterial count in milk ranged from $4 \times 10^{6}$ to $2.7 \times 10^{7}$ per $\mathrm{ml}$. In present study elevated TVC was found than the findings of (Reichart, 1982) who found 0.3 million bacteria/ $\mathrm{ml}$ in raw milk from high quality dairy farm. Which may results from poor hygienic condition of dairy farm and its atmosphere, bacterial count in stable air, use of unhygienic water for washing of udder, unsanitary milking utensil. Stable air influences the hygienic quality of fresh milk (Matkovic, 2006).

Results of this study partially supports the findings of Godefay and Molla (2000) who founded $1.1 \times 10^{5} \mathrm{cfu}$ $/ \mathrm{ml}$ in bucket milk and $4 \times 10^{6} \mathrm{cfu} / \mathrm{ml}$ in storage container before cooling. Present study show increase TVC than his bucket milk count, it may results from relatively poor hygienic condition or increase time in sample transportation and preparation process. Standard plate count (SPC) increased with increasing the storage period Zeng et al. (2007). Present study strongly differ from the findings of Pandey et al. (1996), who founded standard plate count of raw milk $\log 7.66$ to $\log 9.15$ per $\mathrm{ml}$ in area where sanitary quality of in approximately $45 \%$ raw milk was not acceptable. The lowest TVC in present study may results from better sanitary condition of present study area than the previous study. It also indicates the sanitary quality of present study areas are not in unacceptable category. Total bacterial count reflects sanitary quality of food and degree of freshness Dickens et al. (1992) and Stern et al. (1995) and high counts reflects possible adverse effects on public health Sharma et al. (2005). 


\section{R. Khaton and others}

Table 1. Microorganisms (TVC, TCC and TSC) in milk samples collected from different experimental areas

\begin{tabular}{|c|c|c|c|c|c|c|c|c|c|}
\hline \multirow[t]{2}{*}{ Areas } & \multirow[t]{2}{*}{ Samples } & \multirow[t]{2}{*}{$\begin{array}{l}\text { TVC } \\
\text { value } \\
\text { obtained }\end{array}$} & \multirow[t]{2}{*}{$\begin{array}{l}\text { TVC } \\
\text { value } \\
\text { obtained }\end{array}$} & \multirow[t]{2}{*}{$\begin{array}{l}\text { TVC value } \\
\text { obtained }\end{array}$} & \multicolumn{2}{|c|}{$\begin{array}{l}\text { Usual range of } \\
\text { TVC, TCC and } \\
\text { TSC/ ml }\end{array}$} & \multicolumn{3}{|c|}{$\begin{array}{l}\text { Bacterial counts/ml in } \\
\text { log value } \\
\text { (Mean } \pm \text { SD }\end{array}$} \\
\hline & & & & & Min. & Max. & TVC & TCC & TSC \\
\hline \multirow[t]{5}{*}{ Area 1} & I & 5.63 & 2.50 & 2.97 & 5.28 , & 5.85 , & $5.546 \pm$ & $2.526 \pm$ & $2.782 \pm$ \\
\hline & II & 5.85 & 2.62 & 2.62 & 2.36, & 2.74, & 0.221 & 0.155 & 0.154 \\
\hline & III & 5.28 & 2.41 & 2.76 & 2.62 & 2.97 & & & \\
\hline & IV & 5.58 & 2.74 & 2.91 & & & & & \\
\hline & V & 5.39 & 2.36 & 2.65 & & & & & \\
\hline \multirow[t]{5}{*}{ Area 2} & I & 5.42 & 2.59 & 2.74 & & & $5.688 \pm$ & $2.668 \pm$ & $2.792 \pm$ \\
\hline & II & 5.83 & 2.74 & 2.68 & 5.42, & 5.91, & 0.194 & 0.147 & 0.154 \\
\hline & III & 5.59 & 2.68 & 2.94 & 2.47, & 2.86 , & & & \\
\hline & IV & 5.69 & 2.86 & 2.63 & 2.63 & 2.97 & & & \\
\hline & V & 5.91 & 2.47 & 2.97 & & & & & \\
\hline \multirow[t]{5}{*}{ Area 3} & I & 5.87 & 2.77 & 2.94 & & & $5.716 \pm$ & $2.632 \pm$ & $2.796 \pm$ \\
\hline & II & 5.65 & 2.64 & 2.64 & 5.47, & 5.98, & 0.206 & 0.104 & 0.128 \\
\hline & III & 5.47 & 2.52 & 2.84 & 2.52 & 2.77, & & & \\
\hline & IV & 5.98 & 2.54 & 2.82 & 2.64 & 2.94 & & & \\
\hline & $\mathrm{V}$ & 5.61 & 2.69 & 2.79 & & & & & \\
\hline \multirow[t]{5}{*}{ Area 4} & I & 5.64 & 2.64 & 2.79 & & & $5.894 \pm$ & $2.83 \pm$ & $2.898 \pm$ \\
\hline & II & 6.19 & 2.96 & 2.95 & 5.64, & 6.19, & 0.221 & 0.129 & 0.162 \\
\hline & III & 6.03 & 2.91 & 2.68 & 2.64, & 2.96, & & & \\
\hline & IV & 5.74 & 2.88 & 3.09 & 2.68 & 3.09 & & & \\
\hline & $\mathrm{V}$ & 5.87 & 2.76 & 2.98 & & & & & \\
\hline \multirow[t]{5}{*}{ Area 5} & I & 5.68 & 2.66 & 2.79 & \multirow{5}{*}{$\begin{array}{l}5.56 \\
2.47 \\
2.69\end{array}$} & \multirow{5}{*}{$\begin{array}{l}6.23 \\
2.86 \\
3.04\end{array}$} & $5.768 \pm$ & $2.668 \pm$ & $2.876 \pm$ \\
\hline & II & 5.74 & 2.67 & 2.98 & & & 0.266 & 0.147 & 0.141 \\
\hline & III & 6.23 & 2.86 & 3.04 & & & & & \\
\hline & IV & 5.63 & 2.41 & 2.69 & & & & & \\
\hline & V & 5.56 & 2.54 & 2.88 & & & & & \\
\hline
\end{tabular}

$\mathrm{SD}=$ Standard deviation *All the counts are expressed in logarithm

Presence of coliform bacteria, such as E. coli, in milk is a common indicator of fecal contamination. E. coli was isolated from maximum milk samples. The highest coliform bacterial count ( $\log 2.83 \pm 0.129)$ was found in area 4 indicates poor hygienic status of dairy farm in that area, which may results from irregular bathing of animal, feeding of animal in low land, muddy cow yard, unsanitary milking utensil and contamination of body surface by feces. The lowest total coliform count $(\log 2.526 \pm 0.155)$ was found in area 1 might be due to relatively better hygienic condition due to regular bathing, good drainage system, washing of floor and use of relatively better milking utensil (Table 1). Higher prevalence of E. coli was reported by many authors. In Egypt, Aly and Galal (2002) should the presence of $E$. coli in raw milk and the number reduced in the heat treated one. In India, the raw milk and products were heavily contaminated by E. coli Soomro et al. (2002). Present study findings strongly supports with the findings of Saharia et al. (1997), Saitanu et al. (1996) and Zeng et al. (2007) who founded average coliform count of milk within 375 to $500 \mathrm{cfu} / \mathrm{ml}$. In present study relatively lower TCC was found than Hempen (2006), Godefay and Molla (2000) and Uddin et al. (2011) who found coliform counts above $1 \times 10^{4} \mathrm{cfu} / \mathrm{ml}$. It may results from increase use of tube-well water for livestock feeding and management, and washing of udder before milking. This study finding differs from the Alam (1990) who found coliform $130.45 \pm 60.12$ and $92.30 \pm 31.91 \mathrm{cfu} / \mathrm{ml}$ in milk of traditionally and hygienically managed dairy farm. In present study higher count was found than previous it may results from higher coliform counts in farm water, presence of fecal materials on skin surface, poor farm atmosphere, contamination of milk by milkers and utensils.

Coagulase positive Staphylococcus may cause human disease through the production of toxin. The formation of effective levels of toxin requires a high number of microorganisms (approximately $10^{5}-10^{6}$ microorganisms 
per ml of food) IDA (1994). In this experiment, Staphylococcus spp were isolated from the milk samples. In this present study, the highest total staphylococcus count (log $2.898 \pm 0.162)$ was found in area 4 which may results from poor hygienic condition of farms of study areas, presence of subclinical mastitis or contamination from respiratory system and body surface. Staphylococcus spp were the most common cause of intramammary infection (Kyozaire et al. 2005). The lowest staphylococcus count (log $2.782 \pm 0.154)$ was found in area 1 (Table 1) due to good hygienic condition of farms of study areas, absence of subclinical mastitis or contamination free from respiratory system and body surface. Present study supports the findings of Muehlherr et al. (2003) who reported that $90.4 \%$ of raw milk sampled from cows was contaminated by Staphylococcus sp.

From the present study, it can be concluded that the microbiological quality of most of the raw milk samples collected from different arsenic affected and non-affected areas were not satisfactory as some pathogenic bacteria such as Escherichia coli, Staphylococcus spp and Bacillus spp were detected from the samples. The presence of these organisms will render milk unfit for human consumption, since sufficient number of these organisms will cause infection and intoxication. Raw milk should be pasteurized, so that milk remains free from pathogenic microbes. Proper refrigeration temperature should be maintained.

\section{REFERENCES}

1. Awal MA (2001). Environmental pollution: causes of arsenic and nitrite poisoning and their effect on animal body. Report submitted to Ministry of Science and Technology, Bangladesh.

2. Aly SA and Galal EA (2002). Effect of milk pretreatment on the keeping quality of Domiati cheese. Pakistan Journal of Nutrition 1: 132-136.

3. Awal MA (2003). Work progress on detection of arsenic, nitrite and lead and their prophylactic measures in livestock, Ministry of Science, Information and Communication Technology, Bangladesh.

4. Abedin MJ, Feldman J and Meharg AA (2002). Uptake kinetic of arsenic species in rice plants. Plant physiology 128(3): 1120-1128.

5. Alam MZ (1990). Study on milk quality produced traditionally and hygienically under Mymensingh Sadar Upazila. M.Sc. Thesis, Submitted to the Department of Dairy Science, BAU, Mymensingh, Bangladesh.

6. Byron HW, Arnold HJ and Johan AA (1974). Fundamentals of dairy chemistry. $2^{\text {nd }}$ edn, the Avi Publishing Company, Westport, Connecticut.

7. Bramley AJ and McKinnon CH (1990). The microbiology of raw milk, In Robinson, R. K. (Ed.), Dairy Microbiology, Vol. 1, Elsevier Science Publishers, London, p. 163-208.

8. Baird-Parker TC and Tompkin RB (2002). Risk and Microbiological criteria. In The Microbiological Safety and Quality of Food (Vol 11), Lund B, Baird-Parker TC and Gould GW (eds), Aspen Publishers, Maryland, p. $1852-$ 1885.

9. Cody SH, Abbott SL, Marfin AA, Schulz B, Wagner P, Robbins K, Mohle-Boetani JC and Vugia DJ (1999). Two outbreaks of multidrug resistant Salmonella Serotype Typhimurium DT104 infections linked to raw milk cheese in Northern California. Journal of American Medicine Association 281: 1805-1810.

10. Coorevits (2008). Comparative analysis of the diversity of aerobic-spore-forming bacteria in raw milk from organic and conventional dairy farms. Applied Microbiology 31 (2): 126-140.

11. Dickens TA, Cox NA and Greer A (1992). The effects of air scrubbing on moisture pickup, aerobic plate counts. Enterobacteriaceae and the incidence of Salmonellae on artificially inoculated broiler carcasses. Poultry Science 71 (3): 560-564.

12. Godefay B and Molla B (2000). Bacteriological quality of raw cow's milk from four dairy farms and a milk collection centre in and around Addis Ababa. Berl Munch Tierarztl Wochenschr.

13. De Valk H, Delarocque AE, Colomb G, Ple S, Godard E, Grimot P and Desenclos JC (2000). A Community-wide outbreak of Salmonella enteric Serotype Typhimurium infection associated with eating a raw milk soft cheese in France. Epidemiological Infection 124: 1-7.

14. De Buyser ML, Dufour B, Maire M and Lafarge V (2001). Implication of milk and milk products in food-borne diseases in France and in different industrialized countries. International Journal of Food Microbiology 67(1): 117.

15. Harrington P, Archer J, Davis JP, Croft DR, Varma JK and EIC officers. (2002). Outbreak of Campylobacter jejuni infections associated with drinking unpasteurized milk procured through a cow-leasing Program. Wisconsin, 2001. Morbidity and Mortality Weekly Report 51: 548-549.

16. Hempen M (2006). The microbiological quality of raw and sour milk from local markets and smallholder dairy farms and associated potential risk for public health in the Gambia. International Tierg Fachbereiches Veterinarmedizin Germany 32: 157. 


\section{R. Khaton and others}

17. International Commission on Microbiological Specifications for Food (ICMSF) (1986). Sampling for microbiological analysis: Principles and specific applications. In Microorganisms in Food (2 ${ }^{\text {nd }}$ edn), Blackwell Scientific Publications, UK.

18. IDA (1994). Recommendations for the hygienic manufacture of milk and milk based products, appeddix A. Spoilage and pathogenic bacteria in milk based products. International dairy Federation, Belgium, p. 28-30.

19. Jahiruddin M (2002). Arsenic problems in Bangladesh. Department of Soil Science, Bangladesh Agricultural University, Mymensingh, Bangladesh.

20. Kyozaire JK, Veary CM, Petzer IM and Donkin EF (2005). Microbiological quality of goat's milk obtained under different production systems. Journal of Scientific African Veterinary Association 76 (2): 69-73.

21. Lee JT, Park SY, Korea IK and Kin HU (1983). Quality of raw milk in Korea. Korean Journal of Dairy Science 5 (1): 22-28.

22. Merchant IA and Packer RA (1967). Veterinary Bacteriology and Virology. $7^{\text {th }}$ edn. The Iowa State University Press, Ames, Iowa, USA, p. 211-305.

23. Marin AR, Masscheleyn PH and Patrick WH JR (1992). The influence of chemical form and concentration of arsenic on rice growth and tissue arsenic concentration. Plant and Soil 139: 175-183.

24. Mead PS, Slutsker L, Dietz V, McCaig LF, Breese JS, Shapiro C, Griffin PM and Tauxe RV (1999). Food related illness and dead in the United States. Emergency Infectious Diseases 5: 607-625.

25. Muehlherr JE, Zweifet C, Corti S, Blanco JE and Stephan R (2003). Microbiological quality of raw goat's and ewe's bulk-tank milk in Switzerland. Journal of Dairy Science 86 (12): 3849-3856.

26. Matkovic K, Vucemilo M, Vinkovic B, Pavicic Z and Matkovic S (2006). Micro-organisms in stable air as possible postsecretory milk contaminants. MIjekarstvo 56 (4): 369-377.

27. Oliver SP, Jayarao BM and Almeida RA (2005). Food-borne pathogens in milk and the dairy farm environment: food safety and public health implications. Food-borne Pathogens Disease 2 (2): 115-129.

28. Pandey GS, Misra DS, Mule D and Mubita C (1996). Studies on sanitary quality and cell count of raw milk from dairy farm supplying milk to dairy produce board in Luska, Zambia. Bull of Animal Heal and Production in Africa 44 (1): 9-13.

29. Reichart H (1982). Satisfactory raw milk quality as a condition for increased sales of milk products. Dairy Science Abstract 45 (12): 922.

30. Stern NJ, Lyon CE and Musgrove MT (1995). Bacterial quality of broilers and alternative processing procedures. Journal of Applied Poultry Research 4 (2): 164-169.

31. Saitanu A, Chuanchuen KR, Nuanuarsuwan S, Koowatananukul C and Rugkhaw V (1996). Microbiological quality of raw cows milk. Thailand Journal of Veterinary Medicine 26930: 193-214.

32. Saharia J, Saikia S and Bordoloi JP (1997). Influence of housing on coliform counts of cows milk in differentseasons. Indian Veterinary Journal 74 (50): 452-453.

33. Soomra AH, Arain MA, Khaskheli M and Bhutto B (2002). Isolation of Escherichia coli from milk and milk products in relation to public health sold under market conditions at Tandojam. Pakistan Journal of Nutrition 1: 151-152.

34. Sharma R and Pervez S (2005). Toxic metals status in human blood and breast milk samples in an integrated steel plant environment in Central India. Environmental Geochemistry Health 27 (1): 39-45.

35. Sandu M and Man C (2006). Study regarding the milk quality from dairy farms and backyard farms in an industrial processing unit. Medicine Cluj-Napoca 62: 107-110.

36. Tolle A (1980). The microflora of the udder. Factors Influencing the Bacteriological Quality of Raw Milk. International Dairy Federation Bulletin, Document 120.

37. US Public Health Services. (1965). Grade A Pasteurise milk ordinance, U. S. Department of Public Health Education and welfare Service.

38. Uddin MA, Hasan M, Haque MU and Noor R (2011). Isolation and identification of pathogenic Escherichia coli, Klebsiella spp. and Staphylococcus spp. In raw milk samples collected from different areas of Dhaka city, Bangladesh. Stamford Journal of Microbiology 1: 19-23.

39. Zeng SS, Chen SS, Bah B and Tesfai K (2007). Effect of extended storage on microbiological quality, somatic cell count, and composition of raw goat milk son a farm. Journal of Food Product 70 (5): 1281-1285. 